\title{
CYKLICZNOŚĆ CZY ANTYCYKLICZNOŚĆ CEN W POLSCE?
}

\begin{abstract}
Streszczenie
Celem artykułu jest analiza współzależności między zmianami cen konsumpcyjnych i produkcyjnych a produkcji w Polsce w okresie 1995-2015. W pracy wykorzystano metodę badawczą opartą na studiach literaturowych z zakresu makroekonomii i finansów międzynarodowych oraz metody statystyczno-ekonometryczne. Wyniki przeprowadzonych badań sugerują brak obecności zjawiska cykliczności cen konsumpcyjnych oraz występowanie zjawiska cykliczności cen produkcyjnych w krótkim i długim okresie.

Rezultaty badań mają istotne implikacje teoretyczne i praktyczne. W tradycyjnym podejściu do relacji między cenami a produkcja najczęściej zakłada się, że poziom cen jest procykliczny, co oznacza wzrost cen w warunkach wzrostu poziomu produkcji i spadek cen w sytuacji spadku wielkości produkcji. Jednakże wyniki badań przedstawionych w niniejszym artykule wskazują iż przyjęte założenie o cykliczności cen nie zawsze jest właściwe. Wyniki analizy sa także ważne ze względu na politykę pieniężna prowadzoną w kraju, bowiem brak istnienia cykliczności cen konsumpcyjnych wymaga od banku centralnego odmiennych reakcji w odpowiedzi na wahania aktywności gospodarczej w kraju.
\end{abstract}

Słowa kluczowe: cykliczność cen, koniunktura gospodarcza, ceny konsumpcyjne i produkcyjne

\section{CYCLICAL OR ANTI-CYCLICAL PRICES IN POLAND?}

\section{Summary}

The aim of the article is to analyze the interdependence between changes in consumer and producer prices and production in Poland in the period 1995-2015. In the study were used a research methods based on the study of literature in the field of macroeconomics and international finance as well as statisti$\mathrm{cal}$ and econometric methods. The results of the study suggest the absence of the phenomenon of cyclical consumer prices and the phenomenon of cyclical production prices in the short and long run.

Research results have important theoretical and practical implications. In the traditional approach to the relationship between prices and production usually it assumes that the price level is pro-cyclical, which means an increase in prices in the conditions of increase in production and a decline in prices in the situation of a fall in production. However, the results of the study indicate that the accepted assumption about the cyclicality of prices is not always appropriate. The results of the analysis are also important from the monetary policy point of view, as the absence of cyclical consumer price requires from the central bank's different reaction in response to fluctuations in economic activity in the country.

Key words: cyclical prices, business cycle, consumer and producer prices

JEL: E31, E32, F44 


\section{Wstęp}

Na ogół cykl koniunkturalny definiuje się jako periodyczne fluktuacje zagregowanych wielkości ekonomicznych. Burns i Mitchell stwierdzili, że cykl koniunkturalny składa się z następujących po sobie faz: ożywienia, ekspansji, depresji i recesji. Ta sekwencja zdarzeń ma charakter powtarzający, ale nie ma charakteru okresowego. Czas trwania cyklu różni się i waha się od jednego roku do dziesięciu, a czasem nawet dwunastu lat [Burns, Mitchell, 1946]. Z kolei, Lucas oraz Kydland i Prescott zdefiniowali cykl koniunkturalny jako odchylenie zagregowanej realnej produkcji od trendu [Lucas, 1977; Kydland, Prescott, 1990].

Według Lucasa, zrozumienie istoty oraz przebiegu cyklu koniunkturalnego w gospodarce jest punktem wyjścia przy konstruowaniu odpowiedniej polityki stabilizacyjnej kraju. Kraje rozwijające różnią się od gospodarek wysoko rozwiniętych wieloma elementami, w tym przebiegiem wahań koniunkturalnych. W krajach rozwijających się cykle są krótsze, dlatego konieczna jest modyfikacja procedury filtrowania zwyczajowo stosowanej w krajach uprzemysłowionych [Lucas, 1972].

Podejmowane próby wyjaśnienia istniejących zależności między zmiennymi realnymi a nominalnymi współcześnie stanowią ważne źródło debaty wśród ekonomistów. Powszechnie zakładane przez ekonomistów procykliczne kształtowanie się cen, choć nieco paradoksalne, jest analizowane i wyjaśniane za pomocą różnych modeli makroekonomicznych. Przeprowadzone badania w wielu przypadkach przedstawiają dowody sprzeczne z ogólnie przyjętym założeniem o cykliczności cen. Wyniki te, mimo że trudne do wyjaśnienia dzięki standardowym modelom cyklu koniunkturalnego, próbuje się wiązać z szokami popytowymi i podażowymi pojawiającymi się w gospodarkach.

Hipoteza, zgodnie z którą ceny na rynku podążają za zmianami cyklu koniunkturalnego, jest centralnym aspektem w badaniach nad cyklami koniunkturalnymi. W rzeczywistości to założenie jest obecne zarówno w klasycznych, jak i keynesowskiej modelach wyjaśniających współzależności między cyklem koniunkturalnym a wybranymi zmiennymi makroekonomicznymi. Podstawowym argumentem przemawiającym za tą hipoteza jest dominacja zagregowanych szoków popytowych nad zmianami zagregowanej produkcji w krótkim okresie, jak również występowanie opóźnień w dostosowaniu oczekiwań inflacyjnych do zmian podaży i popytu na różnych rynkach. W modelach klasycznych tempo dostosowań oczekiwań inflacyjnych określa termin, w którym wzrostowi inflacji towarzyszy wzrost krajowej produkcji.

Stąd celem niniejszego artykułu jest analiza współzależności między zmianami cen konsumpcyjnych i produkcyjnych a produkcji w Polsce w okresie 1995-2015. W pracy zastosowano metodę badawczą opartą na studiach literaturowych z zakresu makroekonomii i finansów międzynarodowych oraz metody statystyczno-ekonometryczne. Wykorzystane w niej dane statystyczne pochodziły z bazy statystycznej Organizacji Współpracy Gospodarczej i Rozwoju (OECD) i obejmowały okres od drugiego kwartału 1995 roku do czwartego kwartału 2015 roku. 


\section{Współzależności między cenami a cyklem koniunkturalnym w świetle analiz empirycznych}

Generalnie rzecz ujmując, wyniki przeprowadzonych analiz empirycznych, dotyczących wahań koniunkturalnych w krajach wysoko rozwiniętych gospodarczo, wskazuja na występowanie następujących prawidłowości:

a) mają miejsce uporczywe wahania realnej produkcji oraz wahania realnego kursu walutowego;

b) występuje zbliżona zmienność (mierzona odchyleniem standardowym) produkcji, konsumpcji i eksportu netto, podczas gdy zmienność inwestycji jest 2-3 razy większa, a zmienność wydatków rządowych o połowę mniejsza;

c) zachodzi względnie stabilny związek między produkcja, konsumpcją a inflacja;

d) konsumpcja, inwestycje, zatrudnienie oraz inflacja maja charakter procykliczny;

e) realne wynagrodzenia mają charakter procykliczny, kiedy ceny antycykliczny [Male, 2010].

Natomiast badania przeprowadzone wśród krajów rozwijających się świadczą o obecności wyszczególnionych prawidłowości:

a) cykle koniunkturalne są znacznie krótsze i bardziej zmienne niż w krajach uprzemysłowionych;

b) produkcja wyróżnia się większą zmiennością niż w krajach rozwiniętych gospodarczo, a konsumpcja odznacza się większą zmiennością niż produkcja, zaś to jest odmienne od krajów wysoko rozwiniętych gospodarczo;

c) konsumpcja, inwestycje i płace realne sa procykliczne, a to jest zgodne z tym, co obserwuje się w krajach uprzemysłowionych;

d) ceny nie maja charakteru antycyklicznego, a inflacja nie ma charakteru procyklicznego;

e) nie istnieje silny związek między wydatkami rządowymi a produkcją krajową [Male, 2010].

Kydland i Prescott analizowali zjawisko cykliczności cen dzięki badaniu korelacji realnego produktu krajowego brutto (GDP) $z$ indeksem cen konsumpcyjnych (CPI) i realnego PKB z deflatorem produktu narodowego brutto (GNP). Wspomniani ekonomiści ujawnili istnienie istotnej, negatywnej korelacji między PKB a wszystkimi analizowanymi wskaźnikami cen, co wskazywało na występowanie zjawiska antycykliczności cen [Kydland, Prescott, 1990].

Badania przeprowadzone przez Cooley i Ohanian również potwierdziły obecność ujemnej korelacji między zmianami cen a przebiegiem cyklu koniunkturalnego w okresie 1948-1987. Obliczony współczynnik korelacji między ogólnymi zmianami cen a poziomu produkcji wynosił -0,67, zaś po usunięciu trendu za pomocą filtru Hodricka-Prescotta współczynnik ten wynosił-0,57 [Cooley, Ohanian, 1991].

Z kolei, Wolf analizował kształtowanie się cen w USA w warunkach zmian cyklu koniunkturalnego, w okresie przed i po 1973 roku. Wyniki jego badań dowiodły występowania zjawiska cykliczności cen przed 1973 rokiem oraz zjawiska antycykliczności cen po 1973 roku [Wolf, 1991]. 
Natomiast Kim ujawnił w swoich badaniach istnienie w Korei i na Tajwanie ujemnej korelacji cen konsumpcyjnych z cyklem koniunkturalnym oraz dodatniej korelacji wskaźnika inflacji z cyklicznym składnikiem produkcji krajowej w okresie 1995-1996. Zatem wyniki tych badań potwierdziły występowanie zjawiska antycykliczności cen konsumpcyjnych i cykliczności inflacji [Kim, 1996].

Lee analizował współzależności między produkcją krajową a cenami w Kanadzie w XX wieku dzięki wykorzystaniu modelu warunkowej korelacji GARCH. Wyniki analizy udowodniły obecność istotnych współzależności między wspomnianymi zmiennymi, przy czym zmieniały się one znacząco, w szczególności po 2000 roku. Co więcej, współczynnik korelacji między dynamiką produkcji a cen zmienił swój znak z dodatniego na ujemny po 1970 roku [Lee, 2004].

Macchiarelli badał synchronizację inflacji i PKB w kontekście regionalnej integracji gospodarczej wśród siedmiu krajów Europy Środowej i Wschodniej w okresie 1995-2010, uzyskując niejednoznaczne wyniki analizy. Mianowicie, cykliczne zmiany inflacji dowiedziono jedynie w pięciu z analizowanych krajów (t).: w Polsce, na Litwie, Łotwie, w Estonii i Rumunii). Ponadto, w przypadku Polski, Lotwy i Węgier stwierdzono brak podobieństwa zmian inflacji i produkcji w stosunku do krajów członkowskich strefy euro [Macchiarelli, 2013].

Tymczasem Konstantakopoulou z zespołem badał zjawisko cykliczności cen i cykliczności stopy inflacji w dziewięciu krajach OECD, wykorzystując dane kwartalne z okresu 1960-2004. Rezultaty tych badan ujawnily występowanie zjawiska antycykliczności cen oraz zjawiska cykliczności inflacji w analizowanych krajach. Biorąc pod uwagę fakt, że stopa inflacji jest czasową pochodna poziomu cen, to różnica w otrzymanych wynikach analizy zasługuje na uwagę [Konstantakopoulou i in. 2009].

Haslag i Hsu badali współzależności między cyklem koniunkturalnym a cenami oraz cyklem koniunkturalnym i inflacją w USA, w okresie 1947-2012. Wyniki badań potwierdziły występowanie w USA ujemnej korelacji między cyklicznymi komponentami cen a produkcji oraz dodatniej korelacji między cyklicznymi komponentami inflacji a produkcji [Haslag, Hsu, 2012].

Badania o podobnym charakterze zrealizował Mazumder, który analizował współzależności między marżami zysku przedsiębiorstw a poszczególnymi fazami cyklu koniunkturalnego w branży przemysłowej w USA, w okresie 1960-2007. W związku z tym nie badano wyłącznie kształtowania się cen dobór w różnych fazach cyklu koniunkturalnego, ale uwzględniono również zmiany kosztów produkcji w warunkach zmian cyklu koniunkturalnego. Badania te wykazały relatywnie wysoką antycykliczność marż zysków amerykańskich przedsiębiorstw przemysłowych. Ponadto, ujawniono, że antycykliczność marż zysków obejmowała głównie te przedsiębiorstwa, które specjalizowały się w produkcji nietrwałych dóbr konsumpcji [Mazumder, 2014].

Badania przeprowadzone przez $\mathrm{Li}$, dotyczące cyklicznych zachowań poziomów cen oraz stóp inflacji w Stanach Zjednoczonych w okresie 1959-2013, także ujawniły istnienie ujemnej korelacji między cyklicznymi składnikami poziomu cen a produkcji oraz występowanie dodatniej korelacji inflacji i cyklu koniunkturalnego. Zatem oznaczało to, że poziom cen miał charakter antycykliczny, zaś inflacja miała charakter cykliczny [Li, 2015]. 


\section{Metodyka badań}

W celu określenia współzależności między zmianami koniunktury gospodarczej i inflacji w kraju, niezbędne było odróżnienie zmian cyklicznych produkcji i cen od tendencji rozwojowej. Stąd w pracy wykorzystano filtr Hodricka-Prescotta, który zakłada, że składnik cykliczny danej zmiennej stanowi różnicę między jej wartością bieżącą a wartością trendu, a ta jest średnią ważona przeszłych, obecnych i przyszłych obserwacji. Tym samym wskaźnik elastyczności cen na zmiany koniunktury gospodarczej definiuje się jako procentową zmianę odchylenia cen od trendu w stosunku do jednoprocentowej zmiany odchylenia produkcji krajowej od trendu. Analizie współzależności między cyklicznymi zmianami produkcji oraz inflacji konsumenta i producenta w Polsce posłużyły w niniejszym opracowaniu dwa modele o następujących równaniach:

$$
C P I_{t}=\alpha+\sum_{i=1}^{k} \beta_{i} C P I_{t-i}+\sum_{i=1}^{k} \delta_{i} Y_{t-i}+\varepsilon_{t}
$$

gdzie:

$C P I_{t}$ - cykliczne zmiany cen konsumpcyjnych (inflacja konsumenta) w okresie t; $Y_{t}$ - cykliczne zmiany produkcji krajowej w okresie t;

$\beta$ - współczynnik elastyczności cen konsumpcyjnych na zmiany koniunktury gospodarczej.

$$
P P I_{t}=\alpha+\sum_{i=1}^{k} \beta_{i}^{*} P P I_{t-i}+\sum_{i=1}^{k} \delta_{i} Y_{t-i}+\varepsilon_{t}
$$

gdzie:

$P P I_{t}$ - cykliczne zmiany cen produkcyjnych (inflacja producenta) w okresie t; $Y_{t}-$ cykliczne zmiany produkcji krajowej w okresie t;

$\beta^{*}$ - współczynnik elastyczności cen produkcyjnych na zmiany koniunktury gospodarczej.

Wszystkie szeregi czasowe zastosowane w modelach miały częstotliwość kwartalna i obejmowały okres od drugiego kwartału 1995 roku do czwartego kwartału 2015 roku.

Następnie dokonano analizy wzajemnych współzależności między cyklicznymi zmianami cen oraz cyklicznymi zmianami produkcji, posługując się jedną z najczęściej używanych w ekonometrii metod analizy przyczynowości autorstwa Grangera. Głównym jej założeniem jest fakt następstwa przyczynowo-skutkowego, zgodnie z którym, jeżeli skutek występuje w okresie $t$, to przyczyna pojawia się w okresie $t$-k. Zmienna $x$ jest przyczyną w sensie Grangera dla zmiennej $y$, jeśli bieżąca wartość zmiennej $y$ może być przewidywana $z$ większą dokładnościa przy wykorzystaniu minionych wartości zmiennej $x$ niż bez nich, przy pozostałej niezmienionej informacji [Maddala, 2008]. Według powyższej definicji, kwestia weryfikacji przyczynowości w sensie Grangera sprowadza się do analizy, czy zmienna $x$ może być wyeliminowana z tej części modelu wektorowej autoregresji (VectorAutoregression Model - VAR), która opisuje zmiennąy.

Kolejnym etapem analizy było określenie stacjonarności analizowanych szeregów czasowych. W związku z tym zastosowano rozszerzony test Dickeya-Fullera (Aug- 
mented Dickey-Fuller - ADF). W przypadku wszystkich analizowanych zmiennych występowała stacjonarność szeregów czasowych, zatem rząd integracji wynosił 0 .

Analizie współzależności między cyklicznymi zmianami cen konsumpcyjnych, produkcyjnych oraz produkcji w Polsce posłużył model wektorowej autoregresji [Sims, 1980]. Podejście takie po raz pierwszy spożytkował McCarthy, badając różne współzależności makroekonomiczne w krajach członkowskich Organizacji Współpracy Gospodarczej i Rozwoju (OECD), [McCarthy, 1999]. W metodzie VAR analizuje się dane zjawisko za pomocą układu równań, co, według postulatu Simsa, jednocześnie eliminuje problem egzogeniczności zmiennych objaśniających.

W badaniu przyjęto dwa okresy opóźnień czasowych między zmiennymi objaśniającymi a zmienną objaśnianą (dwa kwartały). Wyboru rzędu opóźnień dokonano zgodnie z wynikami kryteriów informacyjnych: Akaike, Schwartza oraz Hannana-Quinna.

Następnie przekształcono model VAR w postać strukturalna, w której występują ortogonalne innowacje, w celu obliczenia i interpretacji funkcji odpowiedzi na impuls oraz dekompozycji wariancji błędów ${ }^{1}$. Dlatego też dalszym etapem analizy był pomiar siły oddziaływania cyklicznych zmian produkcji na cykliczne zmiany cen konsumpcyjnych i produkcyjnych. Pomiaru tego dokonano za pomocą tzw. funkcji odpowiedzi impulsowych (impulseresponsefunction). Funkcja ta określa dynamiczną (rozłożoną w czasie) reakcję $i$-tej zmiennej endogenicznej w modelu VAR na zaburzenie $j$-tego składnika losowego.

Ostatnim etapem badania była dekompozycja wariancji składnika resztowego. Ta procedura pozwala na określenie, jaki udział w wyjaśnianiu wariancji poszczególnych zmiennych modelu mają szoki wpływające na każdą z tych zmiennych. Innymi słowy, w wyniku dekompozycji wariancji mierzy się procentowy udział każdego z poszczególnych szoków (zaburzeń wariancji) w objaśnieniu zmienności poszczególnych zmiennych modelu [Kusideł, 2000].

\section{Analiza cyklicznych zmian cen i produkcji w Polsce}

W polskiej gospodarce miały miejsce stosunkowo istotne, cykliczne zmiany cen produkcyjnych i konsumpcyjnych oraz produkcji w okresie 1995-2015. Jednocześnie należy zaznaczyć, iż cykliczne zmiany produkcji były relatywnie większe niż cykliczne zmiany cen konsumpcyjnych, ale mniejsze niż cykliczne zmiany cen produkcyjnych (rysunek 1.).

Obliczony współczynnik korelacji miedzy cyklicznymi zmianami cen konsumpcyjnych a cyklicznymi zmianami produkcji wyniósł 0,09 , co świadczyło o braku istotnej zależności liniowej między analizowanymi zmiennymi. Zatem na tej podstawie nie udało się potwierdzić występowania zjawiska cykliczności cen w Polsce. Podobnie sytuacja wyglądała w odniesieniu do korelacji między cyklicznymi zmianami cen produkcyjnych a cyklicznymi zmianami produkcji w Polsce. W tym przypadku współczynnik korelacji był jeszcze niższy i wyniósł 0,08 (tabela 1.).

\footnotetext{
${ }^{1}$ Ortogonalne innowacje to innowacje (zaburzenia) niezależnych reszt modelu strukturalnego.
} 
RYSUNEK 1.

Cykliczne zmiany cen konsumpcyjnych, produkcyjnych i produkcji w Polsce, w okresie 1995-2015 (w \%)

CPI

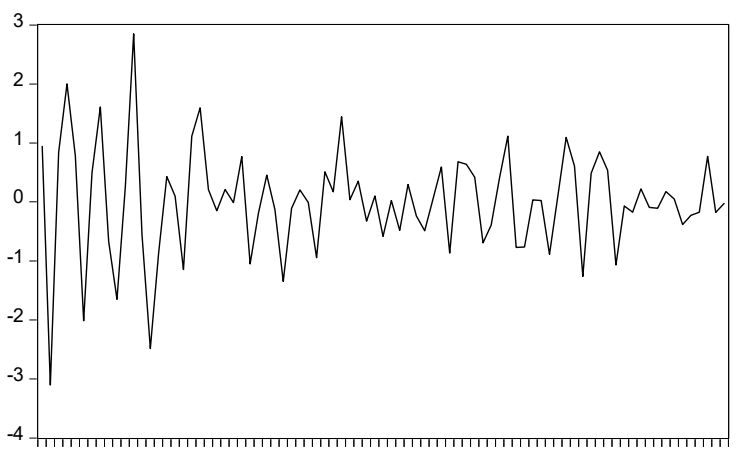

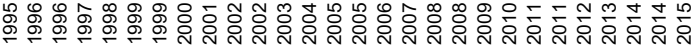
वั่

PPI

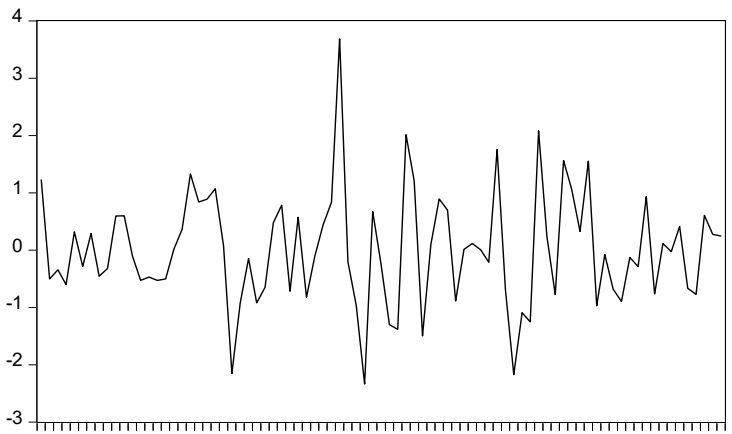

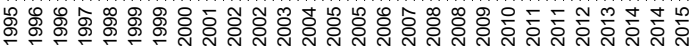
वี่

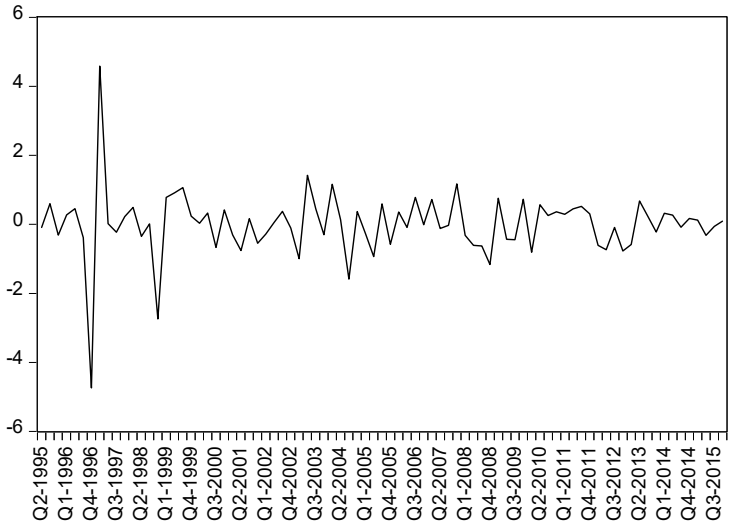

Źródło: opracowanie własne na podstawie bazy danych: [OECD.Stat, 2016]. 
TABELA 1. Współczynniki korelacji między cyklicznymi zmianami cen konsumpcyjnych, produkcyjnych i produkcji w okresie 1995-2015

\begin{tabular}{|c|c|c|c|}
\hline & Y & CPI & PPI \\
\hline Y & 1 & 0,09 & 0,08 \\
\hline CPI & 0,09 & 1 & 0,22 \\
\hline PPI & 0,08 & 0,22 & 1 \\
\hline
\end{tabular}

Źródło: opracowanie własne.

Z kolei, rezultaty przeprowadzonego testu przyczynowości Grangera dowiodły występowania istotnej, lecz jednokierunkowej zależności między cyklicznymi zmianami cen a cyklicznymi zmianami produkcji w Polsce. Otóż na podstawie uzyskanych wyników można stwierdzić, iż nie było podstaw do odrzucenia hipotezy zerowej, zgodnie z którą cykliczne zmiany produkcji nie powodowały cyklicznych zmian cen konsumpcyjnych w Polsce, w okresie 1995-2015. Obliczenia wskazują, że to cykliczne zmiany cen konsumpcyjnych były czynnikiem znacząco determinującym cykliczne zmiany produkcji Polsce, w okresie 1995-2015. Dodatkowo, wyniki testu Grangera potwierdziły to, że cykliczne zmiany produkcji były czynnikiem zasadniczo determinującym cykliczne zmiany cen produkcyjnych w kraju, w badanym okresie (tabela 2.).

TABELA 2.

Wyniki testów przyczynowości Grangera

\begin{tabular}{|c|c|c|c|}
\hline Hipoteza zerowa: & Obs. & F-Stat. & Prawd. \\
\hline Y nie jest przyczyną CPI w sensie Grangera & 81 & 0,236 & 0,790 \\
\hline CPI nie jest przyczyną Y w sensie Grangera & & 3,891 & 0,024 \\
\hline Hipoteza zerowa: & Obs. & F-Stat. & Prawd. \\
\hline Y nie jest przyczyną PPI w sensie Grangera & 81 & 2,685 & 0,074 \\
\hline PPI nie jest przyczyną Y w sensie Grangera & & 0,724 & 0,488 \\
\hline
\end{tabular}

Okres opóźnień: 2 kwartały.

Źródło: opracowanie własne.

Podobne wnioski można wyciagnąć po oszacowaniu równań: (1) i (2) za pomocą modelu wektorowej autoregresji. Obliczony współczynnik elastyczności cyklicznych zmian cen konsumpcyjnych na opóźnione o dwa kwartały cykliczne zmiany produkcji okazał się statycznie nieistotny, co świadczyło o braku występowania zjawiska cykliczności inflacji w Polsce, w krótkim okresie (tabela 3.). 
Wyniki oszacowania równania (1)

\begin{tabular}{|c|c|c|}
\hline & CPI & $\bar{Y}$ \\
\hline $\mathrm{CPI}(-1)$ & $\begin{array}{c}-0,032 \\
(0,086) \\
{[-0,371]}\end{array}$ & $\begin{array}{c}0,272 \\
(0,109) \\
{[2,482]}\end{array}$ \\
\hline CPI(-2) & $\begin{array}{c}-0,552 \\
(0,089) \\
{[-6,139]}\end{array}$ & $\begin{array}{r}-0,126 \\
(0,113) \\
{[-1,117]}\end{array}$ \\
\hline $\mathrm{Y}(-1)$ & $\begin{array}{r}0,0508 \\
(0,088) \\
{[0,573]}\end{array}$ & $\begin{array}{r}-0,355 \\
(0,111) \\
{[-3,179]}\end{array}$ \\
\hline $\mathrm{Y}(-2)$ & $\begin{array}{c}0,047 \\
(0,086) \\
{[0,551]}\end{array}$ & $\begin{array}{c}-0,162 \\
(0,108) \\
{[-1,492]}\end{array}$ \\
\hline $\mathrm{C}$ & $\begin{array}{r}0,0277 \\
(0,078) \\
{[0,354]}\end{array}$ & $\begin{array}{c}-0,003 \\
(0,098) \\
{[-0,030]}\end{array}$ \\
\hline R-kwadrat & 0,341 & 0,216 \\
\hline Skorygowany R-kwadrat & 0,306 & 0,174 \\
\hline Suma kwadratów reszt & 37,602 & 59,938 \\
\hline Błąd standardowy reszt & 0,703 & 0,888 \\
\hline Statystyka F & 9,859 & 5,241 \\
\hline Logarytm wiarygodności & $-83,854$ & $-102,737$ \\
\hline Kryterium Akaike & 2,193 & 2,660 \\
\hline Kryterium Schwarza & 2,341 & 2,808 \\
\hline Zmienna zależna & 0,026 & $-0,006$ \\
\hline Odchylenie standardowe zmiennej zależnej & 0,844 & 0,977 \\
\hline
\end{tabular}

Źródło: opracowanie własne.

Z kolei, oszacowany współczynnik elastyczności cyklicznych zmian cen produkcyjnych na opóźnione o dwa kwartały cykliczne zmiany produkcji wyniósł w badanym okresie 0,24 , co świadczyło o istotnym, dodatnim wpływie zmian koniunktury gospodarczej na cykliczne zmiany cen. Zatem w tym przypadku można było mówić o występowaniu zjawiska cykliczności cen produkcyjnych w Polsce, w krótkim okresie (tabela 4.). 
TABELA 4.

Wyniki oszacowania równania (2)

\begin{tabular}{|c|c|c|}
\hline & PPI & $\bar{Y}$ \\
\hline PPI(-1) & $\begin{array}{c}0,110 \\
(0,109) \\
{[1,008]}\end{array}$ & $\begin{array}{c}0,127 \\
(0,105) \\
{[1,202]}\end{array}$ \\
\hline PPI(-2) & $\begin{array}{c}-0,219 \\
(0,108) \\
{[-2,023]}\end{array}$ & $\begin{array}{r}-0,015 \\
(0,104) \\
{[-0,151]}\end{array}$ \\
\hline $\mathrm{Y}(-1)$ & $\begin{array}{c}0,189 \\
(0,116) \\
{[1,627]}\end{array}$ & $\begin{array}{c}-0,391 \\
(0,112) \\
{[-3,480]}\end{array}$ \\
\hline $\mathrm{Y}(-2)$ & $\begin{array}{c}0,245 \\
(0,116) \\
{[2,095]}\end{array}$ & $\begin{array}{c}-0,221 \\
(0,112) \\
{[-1,963]}\end{array}$ \\
\hline $\mathrm{C}$ & $\begin{array}{c}-0,008 \\
(0,106) \\
{[-0,076]}\end{array}$ & $\begin{array}{c}-0,004 \\
(0,102) \\
{[-0,041]}\end{array}$ \\
\hline R-kwadrat & 0,114 & 0,152 \\
\hline Skorygowany R-kwadrat & 0,067 & 0,107 \\
\hline Suma kwadratów reszt & 69,979 & 64,840 \\
\hline Błąd standardowy reszt & 0,959 & 0,923 \\
\hline Statystyka F & 2,455 & 3,408 \\
\hline Logarytm wiarygodności & $-109,010$ & $-105,922$ \\
\hline Kryterium Akaike & 2,815 & 2,738 \\
\hline Kryterium Schwarza & 2,962 & 2,886 \\
\hline Zmienna zależna & $-0,008$ & $-0,006$ \\
\hline Odchylenie standardowe zmiennej zależnej & 0,993 & 0,977 \\
\hline
\end{tabular}

Źródło: opracowanie własne.

Następnym etapem analizy był pomiar siły oddziaływania cyklicznych zmian produkcji na cykliczne zmiany cen konsumpcyjnych i produkcyjnych w Polsce, w okresie 1995-2015 za pomocą tzw. funkcji odpowiedzi impulsowych (rysunek 2.). 
RYSUNEK 2.

Funkcja odpowiedzi impulsowych dla równania (1)

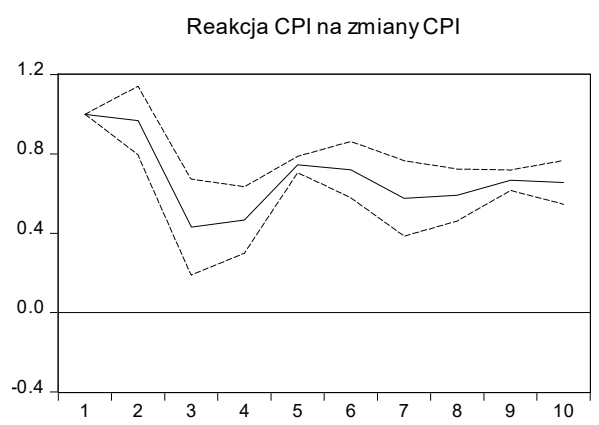

Reakcja CPI na zmiany Y

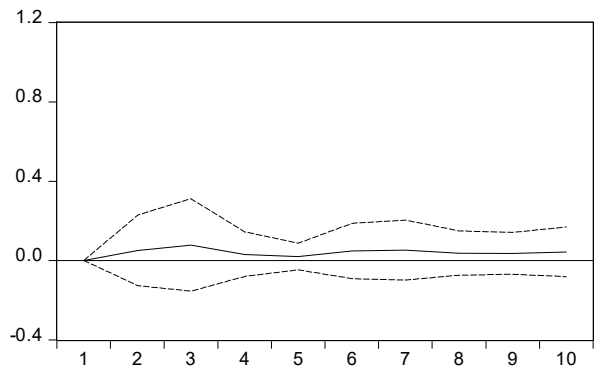

Reakcja Y na zmiany CPI

Reakcja Y na zmiany Y
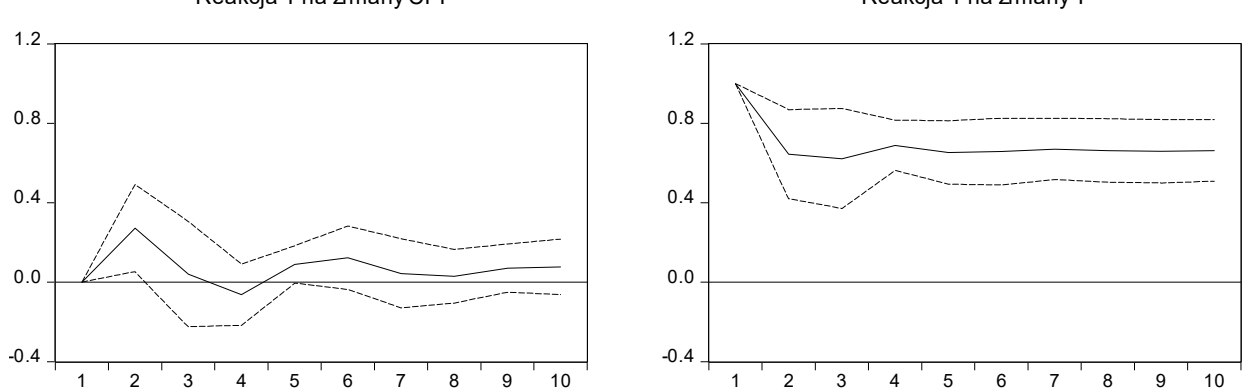

Źródło: opracowanie własne.

Na podstawie powyższych rysunków można dostrzec, iż szokowy wzrost cyklicznej produkcji w zasadzie prowadził do relatywnie niewielkich zmian cyklicznej inflacji w ciągu dziesięciu kolejnych kwartałów od momentu pojawienia się szokowej zmiany. Tym samym potwierdziła się teza o braku występowania cykliczności cen konsumpcyjnych w Polsce, w długim okresie.

Natomiast, analizując powyższe rysunki, można zauważyć, iż szokowy wzrost cyklicznej produkcji przyczyniał się do stopniowego wzrostu cyklicznych cen produkcyjnych w ciagu trzech kolejnych kwartałów od momentu pojawienia się szokowej zmiany cyklicznej produkcji, a następnie do ich stopniowej stabilizacji w ciagu kolejnych dziesięciu kwartałów. Zatem oznaczało to występowanie zjawiska cykliczności cen produkcyjnych w Polsce, w długim okresie (rysunek 3.).

Kolejnym etapem analizy była dekompozycja wariancji składnika resztowego. W tym przypadku dokonano dekompozycji wariancji cyklicznych zmian cen konsumpcyjnych i produkcyjnych w celu oszacowania wpływu zmian analizowanych czynników (opóźnionej cyklicznej zmiany inflacji konsumenta, producenta i produkcji) na kształtowanie się zmienności cyklicznych cen konsumpcyjnych i produkcyjnych w Polsce, w okresie 1995-2015 (tabela 5.). 
RYSUNEK 3.

Funkcja odpowiedzi impulsowych dla równania (2)

Reakcja PPI na zmianyPPI

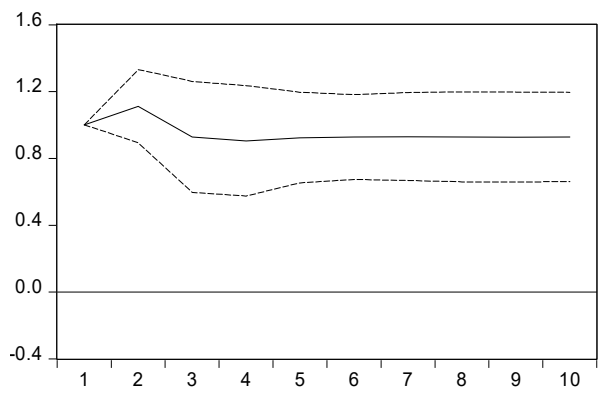

Reakcja Y na zmianyPPI

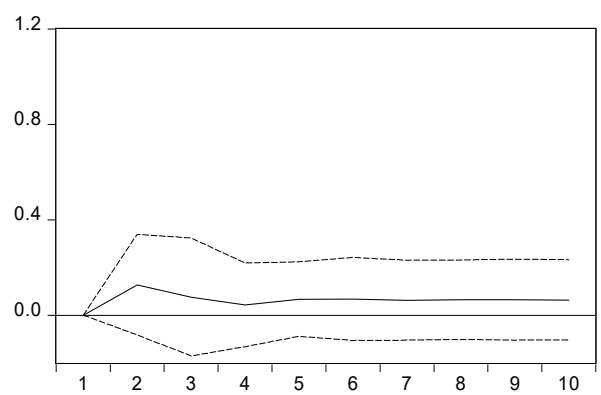

Reakcja PPI na zmiany Y

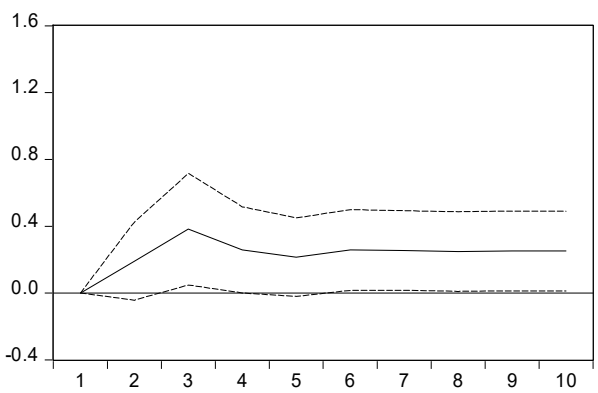

Reakcja Y na zmiany Y

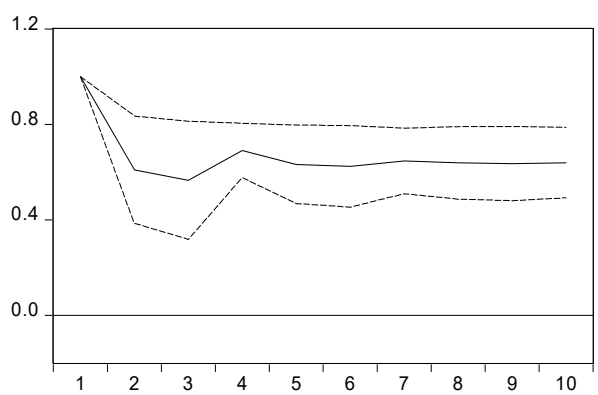

Źródło: opracowanie własne.

Na podstawie danych z tabeli 5. można zauważyć, że cykliczne zmiany produkcji wyjaśniały niespełna $1 \%$ zmienności cyklicznych cen konsumpcyjnych w Polsce, w trakcie dziesięciu kwartałów od momentu wystąpienia szoku cenowego. Natomiast cykliczne zmiany produkcji zdecydowanie tłumaczyły (od ponad 3\% do ponad 8\%) zmienność cyklicznych cen produkcyjnych w trakcie dziesięciu kwartałów od momentu wystąpienia szokowej zmiany. Tym samym można stwierdzić, iż zmienność cyklicznych cen produkcyjnych była bardziej zdeterminowana zmianami koniunkturalnymi w Polsce niż zmienność cyklicznych cen konsumpcyjnych. 
TABELA 5.

Dekompozycja wariancji składnika resztowego dla cyklicznych zmian cen konsumpcyjnych i produkcyjnych w Polsce, w okresie 1995-2015

\begin{tabular}{|c|c|c|c|}
\hline \multicolumn{4}{|c|}{ Dekompozycja wariancji dla zmiennej CPI: } \\
\hline Okres & Błąd standardowy & CPI & Y \\
\hline 1. & 0,703 & 100,000 & 0,000 \\
2. & 0,705 & 99,590 & 0,409 \\
3. & 0,800 & 99,587 & 0,412 \\
4. & 0,801 & 99,318 & 0,681 \\
5. & 0,825 & 99,341 & 0,658 \\
6. & 0,826 & 99,254 & 0,745 \\
7. & 0,832 & 99,263 & 0,736 \\
8. & 0,832 & 99,240 & 0,759 \\
9. & 0,834 & 99,242 & 0,757 \\
10. & 0,834 & 99,236 & 0,763 \\
\hline Okres & Błąd standardowy & PPI & Y \\
\hline 1. & 0,959 & 100,000 & 0,000 \\
2. & 0,984 & 96,915 & 3,084 \\
3. & 1,010 & 94,081 & 5,914 \\
4. & 1,017 & 92,927 & 7,072 \\
5. & 1,018 & 92,791 & 7,208 \\
6. & 1,019 & 92,660 & 7,339 \\
7. & 1,019 & 92,660 & 7,339 \\
8. & 1,019 & 92,656 & 7,343 \\
9. & 1,019 & 92,655 & 7,344 \\
10. & 1,019 & 92,655 & 7,344 \\
\hline
\end{tabular}

Źródło: opracowanie własne.

\section{Podsumowanie}

Wyniki przeprowadzonych badań, sugerujące nieistnienie zjawiska cykliczności inflacji w krótkim i długim okresie oraz obecność zjawiska cykliczności cen produkcyjnych w krótkim i długim okresie, są zdecydowanie zbieżne z wynikami analiz uzyskanymi przez Jędruchniewicza [Jedruchniewicz, 2013], wskazującymi na szybszy wzrost cen produkcji przemysłowej niż cen konsumpcyjnych we wzrostowej fazie cyklu koniunkturalnego, w Polsce.

Rezultaty badań mają istotne implikacje makroekonomiczne, gdyż są szczególnie ważne ze względu na politykę pieniężną prowadzoną w kraju. Otóż brak cyklicznych zmian inflacji oraz cykliczny charakter cen produkcyjnych w krótkim i długim okresie moga prowadzić do asymetrycznej reakcji polityki pieniężnej na wahania aktywności gospodarczej. Mianowicie, skoro nie ma zależności między inflacją a cyklicznymi zmianami produkcji oraz relatywnie niskiej krótko- i długookresowej zależności między cenami produkcyjnymi a cyklicznymi zmianami produkcji w Polsce, to w warunkach 
pogorszenia koniunktury gospodarczej niespadające w dostatecznym stopniu ceny konsumpcyjne oraz ceny produkcyjne ograniczają możliwości banku centralnego we wspieraniu aktywności gospodarczej dzięki obniżce stóp procentowych. Brak wsparcia ze strony polityki monetarnej może nasilać dalsze spadki koniunktury gospodarczej, a nawet opóźniać pojawianie się fazy ożywienia gospodarczego. Natomiast w przypadku rosnącej koniunktury gospodarczej, brak presji inflacyjnej nie zapewnia bankowi centralnemu odpowiedniej swobody $\mathrm{w}$ zakresie prowadzonej polityki monetarnej, a to może spowolnić moment zaostrzenia polityki pieniężnej w kraju.

\section{Literatura}

Burns A. F., Mitchell W. C., 1946, Measuring Business Cycles, NBER Books, New York. Cooley T. F., Ohanian L. E., 1991, The Cyclical Behavior of Prices, "Journal of Monetary Economics", August.

Haslag J. H., Hsu Y. C., 2012, Cyclical Co-Movement between Output, the Price-Level, and the Inflation Rate, "Advances in Econometrics", no. 30.

Jędruchniewicz A., 2013, Struktura cen w polskim cyklu gospodarcsym. Faz̨a wærostu, „Bank i Kredyt", nr 44(1).

Kim Y. W., 1996, Are prices countercyclical? Evidence from East Asian countries, "Federal Reserve Bank of St. Louis Review", no. 78(5).

Konstantakopoulou I., Efthymois T., Kollintzas T., 2009, Stylized Facts of Prices and Interest Rates Over the Business Cycle, "Economics Bulletin", no. 29(4).

Kusideł E., 2000, Modele wektorowo-autoregresyjne VAR. Metodologia $i$ zastosowania, Wydawnictwo Absolwent, Łódź.

Kydland F. E., Prescott E. C., 1990, Business Cycles: Real Facts and a Monetary Myth, "Quarterly Review", vol. 14, no. 2.

Lee J., 2004, The Comovement Between Output and Prices: Evidence from Canada, Texas A\&M University-Corpus Christi, Corpus Christi.

Li X., 2015, The Cyclical Behavior of Prices and Inflation, A Dissertation Presented to the Faculty of the Graduate School at the University of Missouri-Columbia, July.

Lucas R. E., 1972, Expectations and the Neutrality of Money, "Journal of Economic Theory", no. 4.

Lucas R. E., 1977, Understanding Business Cycles, "Carnegie-Rochester Conference Series on Public Policy", vol. 5, Issue 1.

Macchiarelli C., 2013, GDP-Inflation Cyclical Similarities in the CEE Countries and the Euro Area, "ECB Working Paper Series", no. 1552.

Maddala G. S., 2008, Ekonometria, Wydawnictwo Naukowe PWN, Warszawa.

Male R., 2010, Developing country business cycles: Revisiting the stylized facts, "Queen Mary University of London School of Economics and Finance Working Paper”, no. 664.

Mazumder S., 2014, The price-marginal cost markup and its determinants in U.S. manufacturing, "Macroeconomic Dynamics", vol. 18, Issue 04.

McCarthy J., 1999, Pass-Through of Exchange Rates and Import Prices to Domestic Inflation in Some Industrialized Countries, "BIS Working Paper", no. 79. 
OECD.Stat, baza danych, http://stats.oecd.org/, 2016.

Sims Ch. A., 1980, Macroeconomics and Reality, "Econometrica", vol. 1.

Wolf H. C., 1991, Procyclical Prices: A Demi-Myth?, “Quarterly Review”, no. 1524. 